Tropical Journal of Pharmaceutical Research September 2019; 18 (9): 1985-1992

ISSN: 1596-5996 (print); 1596-9827 (electronic)

(1) Pharmacotherapy Group, Faculty of Pharmacy, University of Benin, Benin City, 300001 Nigeria.

\title{
Pharmacokinetic, acute toxicity, and pharmacodynamic studies of semen strychni total alkaloid microcapsules
}

\author{
Xinli Song ${ }^{1}$, Daobin Yang ${ }^{2}$, Yunxia Wang ${ }^{1}$, Wen $\mathrm{Liu}^{3}$, Yonglin Wang ${ }^{4}$, Jiazhen \\ Zhu $^{5}$ \\ ${ }^{1}$ Guiyang University of Chinese Medicine, Dongqing South Road, ${ }^{2}$ Second Affiliated Hospital of Guiyang College of Traditional \\ Chinese Medicine, Feishan Street, ${ }^{3}$ The Affiliated Hospital of Guizhou Medical University, No. 28, Guiyi Street, ${ }^{4}$ Guizhou \\ Medical University, University City, Gui'an New District, Guiyang, Guizhou, ${ }^{5}$ College of Pharmaceutical Science, Zhejiang \\ Chinese Medical University, Gaoke Road, Hangzhou, Zhejiang Province, China
}

*For correspondence: Email: songxinlili@sina.com; Tel: 0086-851-85598491

Sent for review: 27 December 2018

Revised accepted: 24 August 2019

\begin{abstract}
Purpose: To investigate the safety and effectiveness of semen strychni total alkaloid microcapsules (SSTAM), compared with semen strychni total alkaloids (SSTA).

Methods: Liquid chromatography-tandem mass spectrometry (LC-MS/MS) was employed to assess pharmacokinetics of brucine and strychnine in rats. Acute toxicity was investigated in pre-test and formal experiments in mice. The pharmacodynamics of SSTAM and SSTA were evaluated by their analgesic and anti-inflammatory activities.

Results: With respect to brucine, the half-life of SSTA group (1.6 mg/kg), low-dose SSTAM group (6 $\mathrm{mg} / \mathrm{kg}$ ) and high-dose SSTAM group (10 mg/kg) was 5.723, 9.321 and $9.025 \mathrm{~h}$, respectively. With respect to strychnine, the half-life of SSTA group, low-dose SSTAM group and high-dose SSTAM group was 4.065, 8.819 and $8.654 \mathrm{~h}$, respectively. The $L D_{50}$ values of SSTAM group and SSTA group were 236.59 and $30.27 \mathrm{mg} / \mathrm{kg}$, respectively. The pain inhibition rates of SSTAM groups (25 and $50 \mathrm{mg} / \mathrm{kg}$ ) were higher than that of SSTA group $(p<0.05)$ while the pain threshold values of the SSTAM groups $(25$ and $50 \mathrm{mg} / \mathrm{kg}$ ) were higher than that of blank control $(p<0.01)$ and SSTA groups $(p<0.01)$ at 60 min and $120 \mathrm{~min}$. The inhibition rates of the SSTAM groups (25 and $50 \mathrm{mg} / \mathrm{kg}$ ) were higher than that of SSTA group based on ear swelling and cotton ball granulation tests. Compared with blank control and SSTA groups, the absorbance values of SSTAM groups $(25$ and $50 \mathrm{mg} / \mathrm{kg})$ were lower $(p<0.01)$.

Conclusion: SSTAM increases the dosage of administration but reducea the toxicity of the alkaloids in rats, and is thus a potentially safe and effective drug delivery system.
\end{abstract}

Keywords: Pharmacokinetics, Acute toxicity, Pharmacodynamic, Semen strychni, Total alkaloids, Microcapsules, Brucine, Strychnine

This is an Open Access article that uses a fund-ing model which does not charge readers or their institutions for access and distributed under the terms of the Creative Commons Attribution License (http://creativecommons.org/licenses/by/4.0) and the Budapest Open Access Initiative (http://www.budapestopenaccessinitiative.org/read), which permit unrestricted use, distribution, and reproduction in any medium, provided the original work is properly credited.

Tropical Journal of Pharmaceutical Research is indexed by Science Citation Index (SciSearch), Scopus, International Pharmaceutical Abstract, Chemical Abstracts, Embase, Index Copernicus, EBSCO, African Index Medicus, JournalSeek, Journal Citation Reports/Science Edition, Directory of Open Access Journals (DOAJ), African Journal Online, Bioline International, Open-J-Gate and Pharmacy Abstracts

\section{INTRODUCTION}

Semen strychni is the dry ripe seed of Strychnas nux-vomica $L$ [1]. Semen strychni is rich in alkaloids, including brucine, strychnine, brucine $\mathrm{N}$-oxide, strychnine $\mathrm{N}$-oxide, pseudo-brucine, pseudo-strychnine and icajine, which are active anti-tumor ingredients. In semen strychni total 
alkaloids, brucine and strychnine are two major ingredients. Brucine has anti-tumor and antiinflammatory effects, and is less toxic than strychnine. It has significant inhibitory and antiangiogenic effects on liver cancer, lung cancer, colon cancer, breast cancer and multiple myeloma [2-6]. However, because the toxic dose is close to the effective dose, the therapeutic window is narrow, thus clinical application is limited.

Microencapsulation, a well-known technology for drug delivery, has drawn extensive research attention, recently [7-9]. Natural or synthetic macromolecule materials, which are employed as capsule wall materials, can also be used to prepare microcapsules. solid or liquid pharmaceutical preparations can both be packaged into microcapsules. Especially, the microencapsulation technology has been applied in the field of traditional Chinese medicine [10], though it is still at the laboratory research stage. In terms of slow drug release and low toxicity, the microencapsulation technology has promising potential in drug delivery.

Herein, we employed liquid chromatographytandem mass spectrometry (LC-MS/MS) to assess the pharmacokinetics of brucine and strychnine in semen strychni total alkaloid microcapsules (SSTAM) and semen strychni total alkaloids (SSTA). Besides, based on an acute toxicity test, the dosage of SSTAM was confirmed. Furthermore, the pharmacodynamics of SSTAM was investigated, in comparison with SSTA.

\section{EXPERIMENTAL}

\section{Reagents and animals}

Semen strychni total alkaloid microcapsules (SSTAM) and semen strychni total alkaloids (SSTA) were prepared by the Pharmaceutical Preparation Laboratory of Guiyang College of Traditional Chinese Medicine. Brucine reference substance (lot no. 110706-201505, [purity $\geq 98$ $\%]$ ) and strychnine reference substance (lot no. 110706-201507, [purity $\geq 98 \%$ ]) were supplied by Beijing Shengshi Kangpu Chemical Technology Research Institute. Aspirin (lot no. 110606) was obtained from Shenyang Aohua Pharmaceutical Co. Ltd (Shenyang, China). Indomethacin reference substance (lot no. 100258-200904, $99.9 \%$ purity) was provided by National Institute for Drug and Food Control. KunMing mice (KM mice, SPF grade, weight $20 \pm$ $2 \mathrm{~g}$, male-to-female ration $=1: 1$ ) and SpragueDawley rats (SD rats, SPF grade, weight $300 \pm$ $50 \mathrm{~g}$, male-to-female ratio, 1:1) were provided by the Institute of Experimental Animals (Guizhou Medical University). The quality certificate no. of the experimental animals was SCXK (Qian) 2012-0001. Prior to the study, approval was obtained from the Ethics Committee of Guiyang University of Chinese Medicine.

\section{Drug administration and blood collection}

Eighteen SD rats were used for pharmacokinetic study. They were divided into 3 groups randomly, based on intragastric administration: high-dose SSTAM group (10 mg/kg), low-dose SSTAM group $(6 \mathrm{mg} / \mathrm{kg})$ and SSTA group $(1.6 \mathrm{mg} / \mathrm{kg})$. The brucine dose $(0.30 \mathrm{mg} / \mathrm{kg})$ was same in SSTA group and low-dose SSTAM group and so was the strychnine dose $(0.22 \mathrm{mg} / \mathrm{kg})$. Blood was drawn from the orbital venous plexus of rats using glass capillaries at $15,30,60,90,120$, 240, 360, 480, 600, 720 and $1440 \mathrm{~min} ; 0.5 \mathrm{~mL}$ blood was drawn into $1.5 \mathrm{~mL}$ centrifuge tubes.

Plasma samples (200 $\mu \mathrm{L})$ were obtained, contained in the tube with $10 \mu \mathrm{L}$ of heparin sodium, which was as an anticoagulant. Afterwards, the samples mixed with $20 \mu \mathrm{L}$ of methanol and $20 \mu \mathrm{L}$ of internal standard solution (1080 ng/mL of indomethacin) and vortexed for $30 \mathrm{sec}$. Subsequently, $1 \mathrm{~mL}$ of chloroform was added and the samples were vortexed for 30 sec, subjected to ultrasound for $5 \mathrm{~min}$, vortexed for another $30 \mathrm{sec}$ and centrifuged at $5000 \mathrm{rpm}$ for $5 \mathrm{~min}$. The samples were dried by nitrogen at $37{ }^{\circ} \mathrm{C}$, re-dissolved with $100 \mu \mathrm{L}$ of methanol, vortexed for $1 \mathrm{~min}$, subjected to ultrasound for 3 min and centrifuged at $13,000 \mathrm{rpm}$ for $10 \mathrm{~min}$. Eventually, the supernatant was taken out for injection analysis. The pharmacokinetic parameters were acquired by DAS software (V2.0).

\section{LC-MS/MS analysis}

The LC parameters were as follows: the chromatographic column was a Waters BEH C18 $(2.1 \mathrm{~mm} \times 50 \mathrm{~mm}, 1.7 \mu \mathrm{m})$; the mobile phase was $0.2 \%$ formic acid/water-acetonitrile and the volume ratio of the mobile phase was in light of the following gradient elution: $0-0.4 \min (60 \%$ $\mathrm{B} \rightarrow), 0.4-0.6 \mathrm{~min}(60-78 \% \mathrm{~B} \rightarrow), 0.6-1.0 \mathrm{~min}(78$ $\% \mathrm{~B} \rightarrow$ ), 1-1.5 min, (from $78-60 \% \mathrm{~B} \rightarrow$ ) and $1.5-2$ $\min (60 \% \mathrm{~B})$; the flow rate was $0.35 \mathrm{~mL} / \mathrm{min}$; the column temperature was $40{ }^{\circ} \mathrm{C}$. The MS parameters were set as follows: capillary ionization voltage, $3 \mathrm{KV}$; ion source temperature, of $120{ }^{\circ} \mathrm{C}$; desolvation temperature, $550{ }^{\circ} \mathrm{C}$; desolvation gas flow rate, $650 \mathrm{~L} / \mathrm{h}$; blowback gas flow rate, $50 \mathrm{~L} / \mathrm{h}$; cone voltage, $50 \mathrm{~V}$, collision energy, $30 \mathrm{Ev}$; scanning mode, positive ion multireaction ion monitoring mode; quantitative ion of 
brucine, $\mathrm{m} / \mathrm{z} \quad 395.27 \rightarrow 244.11, \quad 324.16$; quantitative ion of strychnine, $\mathrm{m} / \mathrm{z} 335.21 \rightarrow$ 156.04,184.07; and quantitative ion of indomethacin, $\mathrm{m} / \mathrm{z} 358.12 \rightarrow 138.99,110.96$.

\section{Acute toxicity studies}

Forty healthy KM mice were raised for 1 week and divided into the following 10 groups $(n=4)$ : $\operatorname{SSTAM~}(50,100,200,300$, and $400 \mathrm{mg} / \mathrm{kg})$; and SSTA $(5,15,30,40,50 \mathrm{mg} / \mathrm{kg})$. Mice received an intragastric administration of $0.2 \mathrm{~mL} / 10 \mathrm{~g}$, followed by continuous observation of mental status, appearance, activity, and other conditions for 2 weeks; deaths were recorded. Next, 130 $\mathrm{KM}$ mice were fasted for $12 \mathrm{~h}$ and randomly divided into 13 groups $(n=10)$, as follows: SSTA (6 dose groups); SSTAM (6 dose groups); and a saline control group.

The dose ratio of two adjacent groups was designed with a gradient of 1:0.8 and mice received an intragastric administration of 0.2 $\mathrm{mL} / 10 \mathrm{~g}$. The symptoms of poisoning in mice were recorded and the number of deaths within $14 \mathrm{~d}$ were recorded. The LD50 value was calculated according to Eq 1.

$L D_{50}=\lg ^{-1}\left\{X_{m}-i(\Sigma p-0.5)\right\}$

where $\mathrm{Xm}$ is the logarithm of the maximum dose, $p$ is the mortalities of KM mice in each group, $i$ is the difference between the logarithm doses of two adjacent groups, and $\Sigma p$ is the sum of mortalities in each group.

\section{Pharmacodynamic studies}

\section{Writhing test}

Sixty healthy mice were randomly divided into 6 groups, which are SSTAM (12, 25, and 50 $\mathrm{mg} / \mathrm{kg}$ ) groups; SSTA (3 mg/kg) group; positive control group (aspirin [200 mg/kg]) and blank control group $(0.5 \%$ sodium carboxymethyl cellulose). The gavage dose was $0.2 \mathrm{~mL} / 10 \mathrm{~g}$ with continuous drug for $7 \mathrm{~d}$. Mice were fasted for $12 \mathrm{~h}$ before the experiment. One hour after the last administration, mice were intraperitoneally injected with $0.6 \%$ acetic acid (v/v, $10 \mathrm{~mL} / \mathrm{kg}$ ). The writhing times of mice within $20 \mathrm{~min}$ were recorded after administration. Inhibition rate $(\mathrm{H}$, $\%)$ was calculated as in Eq 2.

$H(\%)=\left(T_{b}-T_{s}\right) / T_{b} \times 100 \%$.

where $T_{b}$ is the mean of writhing time in blank control group, and $T_{s}$ is the mean of writhing time in administration group.

\section{Hot plate test}

Sixty healthy female mice with pain threshold values of 10 - $30 \mathrm{~s}$ were randomly divided into 6 groups as in the writhing test. The pain threshold values of mice $(n=3)$ were measured before administration, and the mean was calculated as the normal pain threshold value before administration. The mice received intragastric administration for 7 days. At 30, 60 and 120 min after the last administration, times that mice licked the hind foot on the hot plate were recorded. Times $>60 \mathrm{sec}$ was recorded as 60 sec.

\section{Ear swelling test}

Mice were fasted for $12 \mathrm{~h}$ before the experiment. Sixty healthy female mice were randomly divided into 6 groups as in the writhing test. The mice received intragastric administration for 7 days and the gavage dose was $0.2 \mathrm{~mL} / 10 \mathrm{~g}$. One hour after the last administration, the front and back of the left ear were smeared with $0.05 \mathrm{~mL}$ of xylene; the right ear served as a blank control. After $1 \mathrm{~h}$, mice were sacrificed, and two ears were cut along the auricle baseline. An 8-mm diameter punch was used to obtain a piece of the ear in the same location of the two ears, and immediately weighed. The difference between the left and right ears was the degree of swelling, and the inhibition rate $(\mathrm{R}, \%)$ was calculated as in Eq 3.

$R(\%)=\left\{\left(S_{b}-S_{s}\right) / S_{b}\right\} 100$

where $S_{b}$ is the mean degree of swelling in the blank control group, $S_{S}$ is the mean degree of swelling in the administration group.

\section{Cotton ball granulation test}

Sixty mice were randomly divided into 6 groups as in the writhing test. After adaptive feeding for 1 week, $10 \mathrm{mg}$ cotton balls (sterilized in an autoclave and dried in a vacuum drier at $55^{\circ} \mathrm{C}$ ) were set on the bilateral axillae of mice by subcutaneous implantation under sterile condition. Six hours later, intragastric administration was performed once a day for six consecutive days. Mice were sacrificed on the seventh day. The cotton balls were taken out carefully, dried in a vacuum drier at $55^{\circ} \mathrm{C}$ to constant weight. The weight of the cotton ball before implantation was subtracted to determine the granuloma mass, and the inhibition rate $(B$, $\%)$ was calculated as in Eq 4.

$B(\%)=\left\{\left(M_{b}-M_{s}\right) / M_{b}\right\} 100$ 
where $M_{b}$ is the mean of granuloma mass in blank control group, $M_{s}$ is the mean of granuloma mass in administration group.

\section{Hyperfunction test for abdominal capillary permeability}

Sixty mice were randomly divided into 6 groups as in the writhing test. One hour after the last administration, $1 \%$ Evans blue $(0.1 \mathrm{~mL} / 10 \mathrm{~g})$ was injected into the caudal vein and $0.2 \mathrm{~mL}$ of $0.6 \%$ glacial acetic acid was injected intraperitoneally. After $20 \mathrm{~min}$, the mouse was sacrificed and the abdominal wall was washed thrice with $5 \mathrm{~mL}$ of normal saline. The washing solution was collected in $10 \mathrm{~mL}$ of $\mathrm{EP}$ and centrifuged at $2500 \mathrm{r} / \mathrm{min}$ for $5 \mathrm{~min}$. The supernatant of the sample was measured with a UV-visible spectrophotometer at $590 \mathrm{~nm}$, and the permeability of the abdominal capillary was evaluated based on the absorbance.

\section{Statistical analysis}

SPSS 16.0 statistical software (SPSS, Inc, Chicago, IL, USA) was employed to perform the statistical processing of the experimental data. Data were expressed as mean \pm SD, and MannWhitney $U$ test was employed to determine significance between two groups. $P<0.05$ was considered statistically significant.

\section{RESULTS}

\section{Pharmacokinetics of brucine and strychnine}

Pharmacokinetics parameters of brucine and strychnine were exhibited in Table 1. After model fitting, it was shown that strychnine in mice conformed to a two-compartment model. The half-life of brucine in the low- and high-dose SSTAM groups were $9.321 \mathrm{~h}$ and $9.025 \mathrm{~h}$, respectively, and $5.723 \mathrm{~h}$ in the SSTA group. The peak time in the low- and high-dose SSTAM groups were 2.167 and $2.333 \mathrm{~h}$, respectively, and $0.5 \mathrm{~h}$ in the SSTA group. The peak concentration of the low- and high-dose SSTAM groups was 114.882 and $70.741 \mathrm{ng} / \mathrm{L}$, respectively, and $102.358 \mathrm{ng} / \mathrm{L}$ in the SSTA group. The half-life of strychnine in the low- and high-dose SSTAM groups were 8.819 and 8.654 $h$, respectively, and $4.065 \mathrm{~h}$ in the SSTA group. The peak time in low- and high-dose SSTAM groups were 2.083 and $2.583 \mathrm{~h}$, respectively, and $0.5 \mathrm{~h}$ in the SSTA group. The peak concentration in the low- and high-dose SSTAM groups was 102.546 and $66.621 \mathrm{ng} / \mathrm{L}$, respectively, and $97.221 \mathrm{ng} / \mathrm{L}$ in the SSTA group (Table 1). These results indicated that SSTAM had a significantly slower release rate, longer peak time and more stable plasma concentration.

\section{Toxicologic results for pre-experiment}

Four mice died in the $400 \mathrm{mg} / \mathrm{kg}$ SSTAM group, while there were no deaths in the 50 and 100 $\mathrm{mg} / \mathrm{kg}$ groups. 4 mice died in the $50 \mathrm{mg} / \mathrm{kg}$ SSTA group, while there were no deaths in the 5 and $15 \mathrm{mg} / \mathrm{kg}$ groups (Table 2). Combined with experimental observations, the main manifestations of poisoning were shortness of breath, low bend over, clonic convulsions and piloerection. Stiffness straight of two hind limbs and stiff tail were the symptoms of death.

\section{Toxicologic results for full experiment}

In the highest- and high-dose SSTA groups, toxicity symptoms and death occurred about $11 \mathrm{~s}$ after administration.

Table 1: Pharmacokinetic parameters of brucine and strychnine

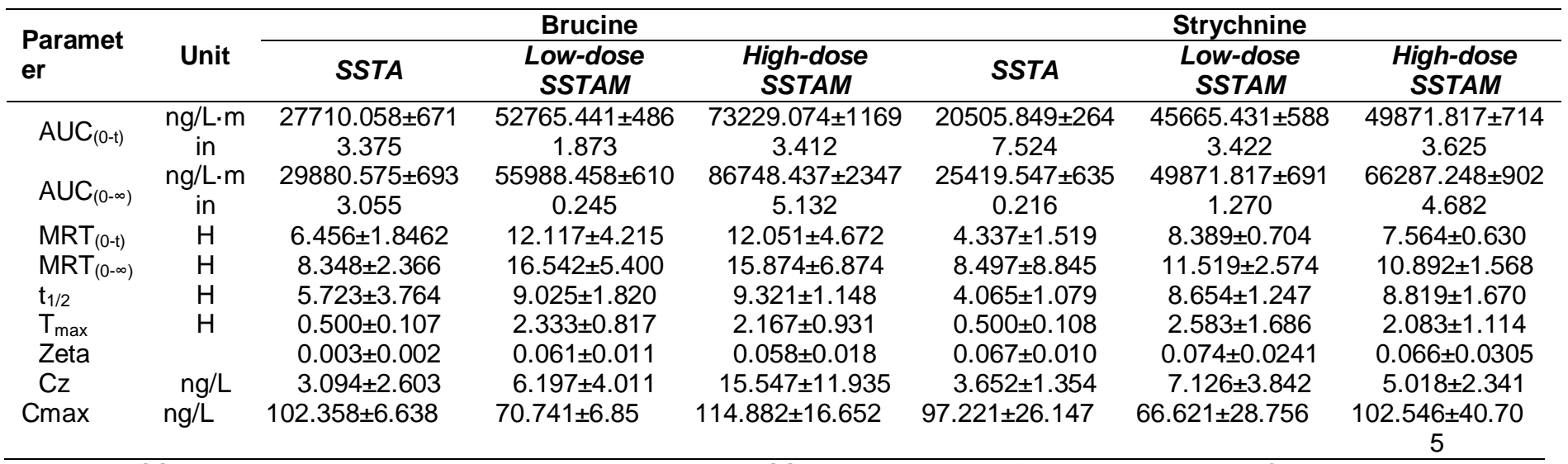

SSTAM, semen strychni total alkaloid microcapsules; SSTA, total alkaloid of semen strychni; AUC, area-undercurve; MRT, multiple-relaxation-time 
Table 2: Number of deaths in mice in pre-test experiment $(n=4)$

\begin{tabular}{lcc}
\hline Group & Dose $(\mathbf{m g} / \mathbf{k g})$ & Number of deaths \\
\hline \multirow{3}{*}{ SSTAM } & 50 & 0 \\
& 100 & 0 \\
& 200 & 1 \\
& 300 & 3 \\
& 400 & 4 \\
SSTA & 5 & 0 \\
& 15 & 0 \\
& 30 & 2 \\
& 40 & 3 \\
\hline
\end{tabular}

SSTAM, Semen strychni total alkaloid microcapsules; SSTA, total alkaloids of semen strychni

As the dose gradually decreased, the number of poisoned mice decreased, the poisoning time prolonged and the number of dead mice decreased (Table 3). In the highest dose SSTAM group, toxicity symptoms and death occurred approximately $20 \mathrm{sec}$ after administration. As the dose gradually decreased, the latent period of toxic symptoms increased. Death occurred after the symptoms remained for approximately 30 sec. Some mice showed only mild toxicity, and the low-dose group did not show toxicity symptoms. Mice that were not dead within 1 day after administration were continuously observed for 14 days, and no deaths occurred. The LD50 value of SSTA was $30.27 \mathrm{mg} / \mathrm{kg}$ (95\% Cl: 26.68 - $34.35 \mathrm{mg} / \mathrm{kg}$ ). The LD50 value of SSTAM was $236.59 \mathrm{mg} / \mathrm{kg}$ (95\% Cl: 157.62 - $355.14 \mathrm{mg} / \mathrm{kg}$ ). The LD50 value of SSTAM was 2.23 times the SSTA, indicating that SSTAM could increase the dosage of administration and reduce the toxicity of strychni semen.

\section{Analgesic effects}

Writhing and hot plate tests were performed to evaluate analgesic effects. The pain inhibition in the $50 \mathrm{mg} / \mathrm{kg}$ SSTAM group was $50.2 \%$, which was statistically significant compared with the blank control group $(p<0.01)$. In addition, there was a significant difference between SSTA and SSTAM (25 and $50 \mathrm{mg} / \mathrm{kg}$ ) groups $(p<0.05)$. The pain inhibition rate of the $12 \mathrm{mg} / \mathrm{kg}$ SSTAM group was $30.5 \%$, and there was no difference compared with the blank control group $(p>0.05)$, while the same result was found between the SSTA and blank control groups $(p>0.05)$. These results indicated that the high-dose SSTAM groups had an apparent analgesic effect to reduce twisting times, but low-dose SSTAM and SSTA groups had no analgesic effect because the low dose did not reach an effective concentration. As shown in Table 4, the pain threshold values of the SSTAM groups (25 and $50 \mathrm{mg} / \mathrm{kg}$ ) were higher than blank control group $(p<0.01)$ and the SSTA group $(p<0.01)$ at 60 and 120 min. Compared with blank control group, the pain threshold value of the SSTA group was increased at 30 and 60 min $(p<0.05$; Table 4). The results suggested that high-dose SSTAM had a higher pain threshold value, as well as a better analgesic effect.

\section{DISCUSSION}

By comparing the pharmacokinetic parameters of SSTAM and SSTA, we could find that through microencapsulation, the peak time and the release of brucine and strychnine were prolonged, and the in vivo stability of brucine and strychnine was improved. The LD50 value of SSTAM was 2.33 -fold versus SSTA, indicating that SSTAM improved the safety dose. With the increase in dose, the effect was increased, thus showing a dose-effect relationship. SSTAM slowed the rate of drug release, reduced the peak of plasma concentration, and expanded the safe dose. Accordingly, SSTAM could increase the dosage of administration and reduce the toxicity of strychni semen.

Table 3: Number of deaths of mice $(n=10)$

\begin{tabular}{lccc}
\hline Group & Dose $\mathbf{( m g} / \mathbf{k g})$ & Dose logarithm & Number of deaths \\
\hline & 15.52 & 1.91 & 0 \\
SSTAM & 19.40 & 1.30 & 1 \\
& 24.40 & 1.38 & 2 \\
& 30.60 & 1.49 & 5 \\
& 38.40 & 1.60 & 7 \\
& 48.00 & 1.68 & 10 \\
SSTA & 110.10 & 2.04 & 0 \\
& 137.62 & 2.14 & 2 \\
& 196.60 & 2.30 & 3 \\
& 254.76 & 2.41 & 4 \\
& 307.20 & 2.49 & 7 \\
\end{tabular}


Table 4: Writhing and hot plate test results

\begin{tabular}{|c|c|c|c|c|c|c|c|}
\hline \multirow{3}{*}{ Group } & \multirow{3}{*}{$\begin{array}{c}\text { Dose } \\
(\mathrm{mg} / \mathrm{kg})\end{array}$} & \multicolumn{2}{|c|}{ Writhing test } & \multicolumn{4}{|c|}{ Hot plate test } \\
\hline & & \multirow{2}{*}{$\begin{array}{l}\text { Writhing } \\
\text { times }\end{array}$} & \multirow{2}{*}{$\begin{array}{c}\text { Inhibition rate } \\
\text { (\%) }\end{array}$} & \multirow{2}{*}{$\begin{array}{c}\text { Before } \\
\text { administration }\end{array}$} & \multicolumn{3}{|c|}{ After administration } \\
\hline & & & & & 30 min & $60 \mathrm{~min}$ & 120 min \\
\hline Blank control & - & $53.2 \pm 8.6$ & - & $18.5 \pm 2.4$ & $22.4 \pm 2.6$ & $19.3 \pm 3.2$ & $21.3 \pm 3.1$ \\
\hline $\begin{array}{l}\text { Positive } \\
\text { control }\end{array}$ & 200 & $28.9 \pm 3.5^{\star}$ & 45.7 & $17.6 \pm 3.1$ & $30.0 \pm 3.1^{*}$ & $37.2 \pm 4.5^{\star}$ & $24.8 \pm 3.8$ \\
\hline SSTA & $\begin{array}{c}3 \\
12\end{array}$ & $\begin{array}{l}39.6 \pm 4.5 \\
37.0 \pm 4.0\end{array}$ & $\begin{array}{l}25.6 \\
30.5\end{array}$ & $\begin{array}{l}19.3 \pm 3.4 \\
17.5 \pm 4.8\end{array}$ & $\begin{array}{l}26.3 \pm 2.7 \\
20.2 \pm 1.6\end{array}$ & $\begin{array}{l}24.4 \pm 2.5 \\
27.6 \pm 1.0\end{array}$ & $\begin{array}{l}19.7 \pm 1.8 \\
22.4 \pm 2.2\end{array}$ \\
\hline SSTAM & 25 & $28.8 \pm 4.7^{* \#}$ & 45.9 & $20.9 \pm 3.3$ & $22.5 \pm 2.8$ & $34.3 \pm 3.2^{\kappa \pi} \#$ & $43.2 \pm 3.7^{\star \pi} \#$ \\
\hline & 50 & $26.5 \pm 4.4^{* \star \#}$ & 50.2 & $21.1 \pm 2.7$ & $26.4 \pm 1.6$ & $38.2 \pm 1.1_{\#}^{\pi \#}$ & $44.5 \pm 3.2_{\#}^{\pi \pi}$ \\
\hline
\end{tabular}

SSTAM, semen strychni total alkaloid microcapsules; SSTA, total alkaloids of semen strychni. Compared with the blank control group; ${ }^{*} p<0.05,{ }^{* *} p<0.01$, compared with total alkaloids group, $\# p<0.05, \# \#<0.01$

\section{Anti-inflammatory effect}

Table 5: Ear swelling, cotton ball granulation, and hyperfunction tests for abdominal capillary permeability among different groups

\begin{tabular}{lcccccc}
\hline \multirow{2}{*}{ Group } & \multirow{2}{*}{$\begin{array}{c}\text { Dose } \\
(\mathbf{m g} / \mathbf{k g})\end{array}$} & $\begin{array}{c}\text { Swelling } \\
\text { degree }\end{array}$ & $\begin{array}{c}\text { Inhibition rate } \\
(\%)\end{array}$ & $\begin{array}{c}\text { Granuloma } \\
\text { mass }\end{array}$ & $\begin{array}{c}\text { Inhibition rate } \\
(\%)\end{array}$ & $\begin{array}{c}\text { Absorbance } \\
\text { value }\end{array}$ \\
\cline { 3 - 7 } & - & $13.0 \pm 3.2$ & - & $19.1 \pm 4.6$ & - & $0.7 \pm 0.1$ \\
Blank control & 200 & $3.7 \pm 2.1^{* *}$ & 71.5 & $8.0 \pm 2.8^{* *}$ & 54.0 & $0.2 \pm 0.1^{* *}$ \\
Positive & 3 & $7.8 \pm 4.0^{*}$ & 39.8 & $12.1 \pm 4.3^{*}$ & 30.5 & $0.4 \pm 0.1^{*}$ \\
control & 12 & $9.3 \pm 3.9^{*}$ & 28.3 & $10.0 \pm 2.9^{* *}$ & 42.5 & $0.4 \pm 0.1^{* *}$ \\
SSTA & 25 & $4.2 \pm 2.6^{* * \#}$ & 68.0 & $9.6 \pm 2.5^{* *}$ & 44.5 & $0.3 \pm 0.1^{* * \#}$ \\
& 50 & $6.3 \pm 3.3^{* * \#}$ & 51.4 & $7.7 \pm 2.6^{* *}$ & 55.6 & $0.3 \pm 0.1^{* * \# \#}$ \\
SSTAM & 25 &
\end{tabular}

SSTAM, semen strychni total alkaloid microcapsules; SSTA, total alkaloids of semen strychni. Compared with the blank control group; ${ }^{*} p<0.05,{ }^{* *} p<0.01$, compared with the total alkaloids group; $\# p<0.05, \# \#<0.01$

Recent studies have shown that brucine has a good anti-tumor effect and has an inhibitory effect. Brucine inhibits the transcription of human hypoxia-inducible factor (HIF)-1 gene and attenuates the expression of downstream genes of HIF-1, such as fibrin and matrix metalloproteinase-2 (MMP-2), thereby inhibiting HGP2 and smmc-7721 Cell transfer [2]. Brucine inhibits cell survival signaling transduction of key junction, and phosphorylation of protein kinase B [11]. Brucine induces apoptosis in human multiple myeloma (RPMI8226) cells by retarding the cell cycle and the destruction of mitochondrial membrane proteins and release of cytochrome $\mathrm{C}$ [4].

Strychnine is one of the toxic components of semen strychni and it is more toxic than brucine, but semen strychni has a non-negligible antitumor effect. MTT assay was used to assess the inhibitory effect of brucine and strychnine on human liver cancer cells (HepG2), and the results showed that strychnine also had a significant inhibitory effect on HepG2 cell proliferation [12]. Another study also confirmed that strychnine played a role in inhibiting tumor cell growth and anti-angiogenesis on the human breast cancer cell line, MCF-7, in vitro [13]. Therefore, pharmacokinetic studies on the SSTA of semen strychni and their preparations focused on the active pharmaceutical ingredients, such as brucine and strychnine.

The LC-MS/MS method has been intensively employed to investigate the pharmacokinetics of strychnine and brucine [14,15]. After a single oral administration of the SSTA from semen strychni at 4 dose levels, the $C_{\max }$ and $A \cup C_{0-t}$ of strychnine and brucine increased and were proportional to the oral doses [14]. In present study, pharmacokinetics of strychnine and brucine in SSTAM and SSTA were studied by LC-MS/MS, and the Cmax, and AUCO-t of strychnine and brucine were also proportional to the dose. In a previous study, brucine-loaded stealth liposomes was prepared by the ammonium sulfate gradient method, and the stealth liposomes improved the pharmacokinetics of brucine [16]. The results showed that SSTAM had better pharmacokinetics than SSTA due to the slowed release rate, decreased peak concentration, longer peak time, and more stable 
plasma concentration. With respect to acute toxicity, the $\mathrm{LD}_{50}$ value of SSTAM $(236.59 \mathrm{mg} / \mathrm{kg})$ was 2.23 -fold versus the SSTA $(30.27 \mathrm{mg} / \mathrm{kg})$, indicating that SSTAM could effectively increase the dosage of administration and have less toxicity effect. The previous study found that $\mathrm{LD}_{50}$ value of brucine solution following intravenous injection was $13.17 \mathrm{mg} / \mathrm{kg}$ [16]. Compare with the crude drug, the $\mathrm{LD}_{50}$ value of processed products of semen strychni increased, and the toxicity lowered [17]. The acute toxicity of semen strychni showed a time-effect relationship in a dose-dependent manner [18], consistent with this study.

In this study, pharmacodynamics was evaluated by analgesic effects (writhing and hot plate tests) and anti-inflammatory effects (ear swelling, cotton ball granulation, and hyperfunction tests). Compound brucine prolonged the incubation period of pain caused by a hotplate in mice. A significant dose-effect relationship was noted in the analgesic study, and the apparent pharmacodynamic parameters were as follows: $\mathrm{Ka}=0.09477 / \mathrm{min} ; \mathrm{T} 1 / 2 \mathrm{a}=7.3 \mathrm{~min} ; \mathrm{Ke}=$ $0.00203 / \mathrm{min} ; \mathrm{T} 1 / 2 \mathrm{e}=341.4 \mathrm{~min} ; \mathrm{Tb}=1.3 \mathrm{~min}$; $\mathrm{Tmax}=41.4 \mathrm{~min} ; \mathrm{Emax}=238.5 ; \mathrm{Te}=598.7 \mathrm{~min}$; and Tc $=597.4 \mathrm{~min}$ [19]. The SSTA of the semen strychni transdermal patch improved the pain threshold caused by a hot board and reduced the duration of body writhing caused by acetic acid, showing a marked analgesic effect with high intensity of activity and long endurance time [20].

Semen strychni processed by cooled and heated milk could enhance the analgesic effect and the $\mathrm{LD}_{50}$ in mice, which illustrated the milkimpregnated processing technology could enhance active pharmaceutical effect and reduce the toxicity of strychni semen [21]. The results indicated that the pain inhibition of the high-dose SSTAM group was higher than the other groups and showed a significant analgesic effect to reduce twisting times. The pain threshold values of the high-dose SSTAM group was higher than the other groups. The high-, medium-, and lowdose SSTAM groups had anti-inflammatory effects, by the higher dose had better effects. These results indicated that the SSTAM group showed better analgesic and anti-inflammatory effects than the SSTA group.

\section{CONCLUSION}

The findings of this study indicate that SSTAM reduces the toxicity but enhances the efficiency of strychni semen in an animal model. The results also indicate that the analgesic and antiinflammatory effects on SSTAM group are than that on SSTA group. Further studies in patients are to planned to ascertain the clinical applicability of the findings.

\section{DECLARATIONS}

\section{Acknowledgement}

This work was supported by Education Department of Guizhou Province Science and Technology Top-notch Talent Support Project (Qianjiaohe KY zi[2017]074), Guizhou Health and Family Planning Commision Science and Technology Fund Project (no. gzwjkj2014-1-041), Guizhou Science and Technology Department 2017 Annual Academic New Seedling Cultivation and Innovation Exploration Special Project (Qiankehepingtairencai [2017]5735-26) and Open fund for scientific research of the Firstclass discipline (traditional Chinese medicine) in Zhejiang Province. (no. Ya2017007).

\section{Conflict of interest}

No conflict of interest is associated with this study.

\section{Contribution of authors}

We declare that this work was done by the author(s) named in this article and all liabilities pertaining to claims relating to the content of this article will be borne by the authors". Xinli Song, Daobin Yang conceived and designed the study, Xinli Song, Daobin Yang, Yunxia Wang and Wen Liu collected the data, Xinli Song, Yonglin Wang, Jiazhen Zhu analysed the data, Wen Liu, Yonglin Wang, Jiazhen Zhu wrote the manuscript. All authors read and approved the manuscript for publication in this journal.

\section{Open Access}

This is an Open Access article that uses a funding model which does not charge readers or their institutions for access and distributed under the terms of the Creative Commons Attribution License (http://creativecommons.org/licenses/by/ 4.0) and the Budapest Open Access Initiative (http://www.budapestopenaccessinitiative.org/rea d), which permit unrestricted use, distribution, and reproduction in any medium, provided the original work is properly credited.

\section{REFERENCES}

1. Tian JX, Tian $Y, X u$ L, Zhang J, LU T, Zhang ZJ. Characterisation and identification of dihydroindole-type alkaloids from processed semen strychni by high- 
performance liquid chromatography coupled with electrospray ionisation ion trap time-of-flight mass spectrometry. Phytochem Anal 2014; 25: 36-44.

2. Shu G, Mi X, Cai J, Zhang $X$, Yin W, Yang X, Li Y, Chen $L$, Deng $X$. Brucine, an alkaloid from seeds of Strychnos nux-vomica Linn., represses hepatocellular carcinoma cell migration and metastasis: The role of hypoxia inducible factor 1 pathway. Toxicol Lett 2013; 222: 91 101.

3. Li M, Li P, Zhang M, Ma F, Su L. [Brucine inhibits the proliferation of human lung cancer cell line $P C-9$ via arresting cell cycle]. Zhongguo Fei Ai Za Zhi 2014; 17(6): 444-450.

4. Rao PS, Ramanadham M, Prasad MNV. Anti-proliferative and cytotoxic effects of Strychnos nux-vomica root extract on human multiple myeloma cell line-RPMI 8226. Food Chem Toxicol 2009; 47: 283-288.

5. Serasanambati M, Chilakapati SR, Manikonda PK, Kanala JR, Chilakapati DR. Anticancer effects of brucine and gemcitabine combination in MCF-7 human breast cancer cells. Nat Prod Res 2015; 29: 484-490.

6. Luo W, Wang $X$, Zheng L, Zhan $Y$, Zhang $D$, Zhang J, Zhang $Y$. Brucine suppresses colon cancer cells growth via mediating KDR signalling pathway. J Cell Mol Med 2013; 17: 1316-1324.

7. Mathavan S. Utilization of the microencapsulation technology in the targeted delivery of an antidiabetic lipophilic drug incorporated in a bile acid-alginate hydrogel: hypoglycemic and inflammatory profile analysis. Mark Liveris Research Seminar 2016.

8. Yuan $S, W u Q$, Lei F, Li G, Si T, Xu RX. One-step fabrication of triple-layered microcapsules by a tri-axial flow focusing device for microencapsulation of soluble drugs and imaging agents. SPIE BiOS2016. p. $97111 \mathrm{~F}$.

9. Aina A, Gupta M, Boukari Y, Morris A, Billa N, Doughty S. Monitoring model drug microencapsulation in PLGA scaffolds using $X$-ray powder diffraction. Saudi Pharm J 2016; 24: 227-231.

10. Meng $X, \quad L i$ BG, Qi Z, Wu YQ. Application of microencapsulation technology in traditional Chinese medicine modernization. Food Science and Technology. 2006; 31(9): 4-7.

11. Zheng L, Wang $X$, Luo W, Zhan $Y$, Zhang Y. Brucine, an effective natural compound derived from nux-vomica, induces G1 phase arrest and apoptosis in LoVo cells. Food Chem Toxicol 2013; 58: 332-339.
12. Deng $X K$, Yin W, Li WD, Yin FZ, Lu XY, Zhang XC, Hua $Z C$, Cai BC. The anti-tumor effects of alkaloids from the seeds of Strychnos nux-vomica on HepG2 cells and its possible mechanism. J Ethnopharmacol 2006; 106: 179186.

13. Saraswati S, Mathur R, Agrawal SS. 653 Evaluation of strychnine, a plant alkaloid for in vitro antiangiogenesis, apoptosis and antioxidant potential in MCF-7 cancer cells. European Journal of Cancer Supplements. 2010; 8(7): 204.

14. Lin A, Su X, She D, Qiu K, He Q, Liu Y. LC-MS/MS determination and comparative pharmacokinetics of strychnine, brucine and their metabolites in rat plasma after intragastric administration of each monomer and the total alkaloids from Semen Strychni. J Chromatogr $B$ Analyt Technol Biomed Life Sci 2016; 1008: 65-73.

15. Gu W, Wang D, Pan Z, Liu X, Cai B, Chen J. Ultraperformance liquid chromatography-tandem mass spectrometric assay for the simultaneous determination of brucine, strychnine and brucine $\mathrm{N}$-oxide in rat plasma: application to a pharmacokinetic study. Biomed Chromatogr 2016; 30: 1097-1103.

16. Chen J, Yan GJ, Hu RR, Gu QW, Chen ML, Gu W, Chen $Z P$, Cai BC. Improved pharmacokinetics and reduced toxicity of brucine after encapsulation into stealth liposomes: role of phosphatidylcholine. Int $J$ Nanomed 2012; 2012: 3567-3577.

17. Gong QF, Zhou DG, Zhang DF. Experimental study on acute toxicity of semen strychni and its processed products. Journal of Jiangxi Univ TCM. 2007.

18. Mo WH, Wang $Y H$, Deng DF, Meng P. Effects of micronization on the acute toxicity of semen strychni in mice. Journal TTCM University of Hunan. 2012; 9: 1214.

19. Zhu JW, Wu JB, Li CS. Analgesia and pharmacodynamics of compound brucine injection in mice. Chinese J Information TCM 2005.

20. Qin LI, Ma YS, Yang XZ, Zhang GH. Screening of penetration enhancer and analgesic effect of total alkaloids in Semen Strychni Transdermal Patch. Pract Pharm Clin Remed. 2013; 8: 663-666.

21. Tursun D, Shi YZ, Yang QL, Liu Y, Xue WC, Abas A, Yang WJ. [Influence on strychni semen's analgesic effect and toxicity of milk-impregnated-processingtechnology of Traditional Uighur Medicine]. Zhong Yao Cai. 2015; 38: 267-270. 